DOI: 10.20472/IAC.2018.037.009

ARDIAN KASTRATI

University of Prishtina, Kosovo

\title{
THE ROLE OF CIVIL SOCIETY IN THE EUROPEAN INTEGRATION PROCESS IN KOSOVO: EU MECHANISMS AND INSTRUMENTS FOR NGO SECTOR DEVELOPMENT
}

\begin{abstract}
:
European integration is one of the most demanding processes for Kosovo institutions and society. While citizens of Kosovo overwhelmingly support membership in the European Union, assessment reports specify that Kosovo and its institutions still need serious reform to achieve this goal. The integration process offers mechanisms that civil society namely NGO sector can use in order to monitor and give direct contribution for this process, which could also impact to transform Kosovo institutions and society. The Annual Progress Report of the European Commission requires from governments and institutions of countries aspiring for integration to the EU to pursue sound governance practices that allow civil societies to have an impact on policy and decision-making processes. Relying on this requirement, NGOs can use the process as a way to shape the organization and function in their society and institutions. The role of Kosovo NGO's whose focus is political activism that tends to increase demands for democratic participation in the political system is very important for Kosovo's EU Integration process. NGO's apart from monitoring role towards the Government, they can become one of the main partners for EU Integration Process, especially to the European Commission (EC). The aim of this paper is to analyze the role of NGO's as part of civil society in the whole process of EU integration and current possibilities for improving their capacities and contributions towards the public policy and decision making process.
\end{abstract}

\section{Keywords:}

NGO Sector, EU Integration in Kosovo, Kosovo Institutions, Decision Making

JEL Classification: D72 


\section{Introduction}

It has been observed in various EC reports that civil society organizations in Kosovo are weak. The European integration process needs civil society organizations as its partner, and the EC is committed to developing and supporting it. This is the reason why the EC included provisions for civil society support in its enlargement strategy papers and financial frameworks. In most cases, the European integration process and civil society organizations are natural allies and need each other to progress through the process. Civil Society Organizations in Eastern Europe have used instruments and financial resources provided from EC to design projects for their active participation in defining policies and strategies that have raised public awareness for the EU integration process. The integration into the EU has been the main factor in affecting a transformation of civil society in the Baltic States (Spurga, 2005).

The Annual Progress Report of the European Commission mainly evaluates Kosovo authorities. As the Commission only evaluates the level of development of civil society, it cannot control or regulate civil society as that depends on national authorities (KHDR, 2008). However, NGO sector should secure a better role of the civil society on evaluation of effect of particular laws, public policies and strategies. In general, experience of the South-East European countries has proved that support and participation of the civil society organizations is very important for the accession process. NGO sector in Kosovo through their civic and political activism can and should ensure increased democratic participation in policy making during the EU Integration process, thus increasing monitoring capacities of civil society organizations towards the Government. Besides active participation in the process NGO's can play an important role in monitoring. The monitoring process entails several EU instruments. NGOs can use European Partnerships as instrument to influence the EU integration process.

This article analyzes the impact of the NGO sector for the EU Integration process in Kosovo starting from their role in defining citizen needs, analysis of policy making process, control and evaluation of effect of particular laws and EU compatibility check of the approved laws and their assistance in designing public policies by using EU mechanisms and instruments.

\section{Government - Civil Society cooperation}

The Kosovo Government has not established institutional mechanisms or a policy for developing relations with NGO sector in order to facilitate the inclusion of NGOs in the policy making process. The law on NGOs does not restrict participation of NGOs in the decision-making process however it doesn't regulate government-civil society cooperation and the institutional forms it could take (LAW NO.03/L-134, MPS, 2005). The role of the NGO sector as part of civil society should be to actively provide citizens a 
trustworthy channel through which to respond to state outputs and influence state decision-making by conveying citizen's stands and inputs. Organized and coordinated NGO networks can provide this trustworthy and reliable communicating channel of citizen's wants and needs to the state. If this voice is not seriously heard from state institutions in Kosovo, it will lower the motivation of civil society for advocacy. The level of factual democratization in Kosovo carried out after transition of competences from UNMIK to Kosovo institutions from 2002 onwards is manifested most clearly through the level of civil society development. On the other side the state authority is manifested through marginalization of civil society respectively NGO sector (Sterland, 2006). Recent experiences in Kosovo show that the existence of political parties, of the elected Government and parliament and the media are not sufficient preconditions for the active role of NGO sector as part of civil society in decision making process as long as there is no strategy and mechanisms for cooperation. Government officials cooperate with a very restricted range of known and trusted NGOs, rather than engage in the more politically challenging process of communicating with more NGO leaders, thus allowing more space for NGOs to influence decision making process...' (TACSO, 2010).

Before the declaration of independence the Agency for Coordination of Development and European Integration (ACDEI) was another mechanism of institutional cooperation between the government and civil society The ACDEI has been transformed into the Ministry for European Integration, MEI. The MEI is the government body charged with managing Kosovo's activities towards achieving integration and for coordinating EU support to Kosovo. Other attempts at the central government level to institutionalize a substantive role for civic participation in policy dialogue appear to have been unsuccessful. Although the government superficially recognizes the importance of NGO sector as an important part of civil society, it has no clear vision of helping NGOs to develop because Government structures want to keep more power for themselves (Progress Report for Kosovo, 2009). International Community sponsored mostly NGOs oriented towards providing services as opposed to those interested in direct political activism. Kosovo's Government is not interested in either of them. This is primarily a consequence of highly centralized political party structures in the Government, which prevents most of the NGOs from having greater access to the policy process. On the other hand, there is a very small number of NGOs that actually have explicit and well formulated policy goals which they can actively lobby for' (KIPRED, 2005). The passive role of the NGO sector towards the government sometimes reminds us of the culture of peaceful relations between the two during the 1990s, although at that time the goal of cooperation was a united front and coordinated strategy against the Serbian regime. Consequently, the communication channels between the government and NGO sector remain weak. Much of it is dependent on individuals. If an individual in a government institution has had experience in the NGO sector that can help foster a positive approach towards NGOs. In other situations the cooperation might work if an individual is a 
member of a NGO that supports certain government policies. In the current Government we have many individuals who were appointed as high governmental officials. Regardless of this engagement, there are ad hoc meetings between the government and the NGOs but they lack elements of genuine cooperation. Compared to the government, the cooperation between the parliament and NGO groups is little better. The cooperation of the parliament with NGOs has steadily improved over the years, and now NGOs regularly participate in the activities of the parliament. Representatives of NGOs believe that there is much more room for cooperation.

Kosovo institutions are not the only one to be hold responsible for this weak relationship with the NGOs. Because of its historical roots, Kosovar NGO sector is fragmented. There is a lack of cooperation and solidarity between NGOs and lack of understanding of the broader role that NGO sector should play within the institutional socio-political context. Most of them have proved short-lived and ineffective with few exceptions. Over the years only few NGO's have established more effective networks of cooperation for lobbying and monitoring different projects related to important issues of public interest. (Kipred, 2005).

However, some of the civil society experts still see significant improvements in the relationship between the two sectors with the fact that in recent years (before and after the independence) several ministers, members of parliament and political advisors came from the civil society, respectively NGO sector. Numerous people have left NGOs and joined political parties or the government. The shift from civil society to government is perceived positively, as people who have learned key concepts about management and networking in civil society bring their experience to the government. Although this might be seen as positive step, there is the risk that as NGO elites want to keep the opportunity to become government officials, there will be less pressure from NGO sector towards the government. In general, since the establishment of Kosovo provisional institutions in 2002 and onwards, institutionalized cooperation between the civil society, respectively NGO sector and the Government remains weak. The European Commission's Progress Report for Kosovo 2008 stated: 'Government does not have a strategic approach for cooperation with civil society organizations" (Progress Report for Kosovo, 2008).

\section{EU mechanisms for NGO sector}

Due to Kosovo's unresolved political status, in 2003 a special instrument called the Stability Tracking Mechanism (STM) was designed to enable Kosovo to participate in SAP. Although the STM did not answer the question of contractual relations between Kosovo and EU, it still provided a framework for Kosovo to engage individually (separate from Serbia) in the process (KHDR, 2008). After the declaration of independence, Kosovo moved from the STM process to SAP. But this was difficult, due to the fact that five EU member states have not yet recognized Kosovo's independence, putting the European Commission in a difficult situation and also making negotiations on the Stabilization and 
Association Agreement (SAA) difficult. However, the SAA between the EC and Kosovo is signed in 2015.

One of the main instruments within the SAP that can be used from NGO sector in order to influence the integration process is the European Partnership priorities document. This document was initiated in the Thessaloniki European Council in 2003. The Council has stated that the European Partnerships are a means to materialize the European perspective of the Western Balkans and medium-term reforms which the countries need to carry out, to serve as a checklist against which to measure progress, and to provide guidance for programming of EU assistance (Council Decision of 30 January 2006). European Partnership document is based on the state of play of each country and addresses that country's needs and the actions it needs to undertake in order to move closer to the EU. All actions and recommendations in the Partnerships are based on short-term (one to two years) and medium term (three to four years) reforms that countries need to implement.

European Partnership document requires from the designated country an action plan containing detailed measures, timetables and budgets for implementing them, in order to respond to the priorities of the partnership document. The implementation of the action plan is evaluated annually by the Commission and the progress will be monitored by SAP mechanisms. For example, if access to information is a concern for NGO sector, they should appeal to the European Commission to address this concern within the European Partnership. Consequently, the EC has a huge bargaining power in the process and will address issues regularly with national authorities, and follow up whether the government has implemented their recommendations and report accordingly in the progress report. The fact that EU assistance is based on recommendations in the European Partnership document gives another tool to NGOs to lobby both the EC (in Kosovo, the European Commission Liaison Office) and with national authorities as they complete annual programming. Once their concerns are incorporated into the European Partnership document, NGOs have the right to insist that the measure receives EU financial assistance through the Instrument for Pre Accession (KHDR, 2008).

\section{The influence of NGO sector through EU instruments}

If NGOs want to promote their agendas, they need to actively take part in the EU Integration process although this can be a complex and demanding task. 'One of the wellknown obstacles to enhancing the EU's support to civil society in [candidate] countries is posed by the bureaucratic procedures of aid programs' (Raik, 2006). The timeframe for conclusion of Stabilization Association Agreement (SAA) and membership negotiations (accession) is not known, however it is expected to take considerable time. While SAA is mainly trade related, membership negotiations cover all of the criteria described above and NGOs will be invited to actively take part in this final stage of the process. 
Experience from Eastern European countries that have joined the EU shows that in countries where civil society has been better informed, the more influence it had on this process (Sterland,2006).

Experience has shown that countries in the early stage of integration lack the capacity to implement policies and strategies, and Kosovo is no exception to this. Thus, policymaking is another aspect of the process to be monitored, especially if the laws are enacted on time. Specifically, the NGOs should cooperate with the EU agencies in the country responsible to ensure that each draft law passes an EU compatibility check. Another way to monitor and take part in the integration process is to ask that NGOs participate in the Committee for European Integration in the National Assembly. In general, the role of the NGO sector for the EU integration process in Kosovo is neglected both by the Government and many NGO representatives although NGOs dispose several mechanisms by which it can achieve particular goals and results in a faster and more effective way (USAID, 2008).

\section{Conclusions}

The role of NGO sector in the process of the European integration should be focused on initiating and conducting a more intensive public dialogue on joining of Kosovo to the EU. One of the main goals of these public debate supported from local media should be to inform the public on the process of the European Integration. Public campaigns will also help define citizen's needs. Involvement and activities of the NGOs in the process of reforms and monitoring using EU mechanisms and instruments should be increased. It is also important to define their agendas and build constituencies. Thus, a better cooperation between the Government and NGOs could be established. It is the duty of the Government to create a favorable climate in order for NGOs to become more functional. Because the Government is dominated by rigid party structures it is not expected that they will be the first ones to start this reform. If communication between Government and civil society representatives brings no results NGO representatives could use EU Integration as a process in order to address this concern within the European Partnership instrument.

NGOs are among the most important actors in the complex constellation of stakeholders in the EU Integration process. As the integration process develops in the future, Western Balkan countries will continue working to secure and/or improve present positions with regard to their European agendas. This ultimate goal continues to be challenging and it will call for an action from multiple society layers, whereas NGOs as an important part of civil society can contribute to the quality of and public support for pre-accession related reforms. NGOs could play an indispensable role in sustaining democratic development and good governance, especially against the background of historical complexities and challenges of transition in Kosovo. The leadership of both Kosovo institutions and NGO 
sector in cooperation with international actors involved in Kosovo should prepare a strategy in order to strengthen the role and participation of NGOs in the European integration process. There are several instruments that NGOs can use to participate in the process. Kosovo needs to develop a sustainable triangle between the government, the EU and civil society relations. NGOs need also to reach out more often to their target groups in order to create stronger networks between them. It is important to shun the individualistic and narrow interests when it comes to networking, and see the benefits of NGO joint action, which is ultimately a more powerful force compared to their individual capacities. They need to reach out more to their target groups and apply a more focused approach in their mission, rather than opportunistically shifting towards donor priorities.

NGOs interested in impacting state policies should look for the instruments and mechanisms that will help reshape and improve their cooperation with the Government structures. In order for this to happen a contribution from both NGO sector and of the state is needed. Only when this happens will the new generations of Kosovo NGOs see the state as their protector, and political leaders will see civil society representatives as their supporters rather than a threat to themselves, only then, will a truly vibrant civil society be able to develop in Kosovo. However, this is not an easy mission.

The Republic of Kosovo, in its tenth year as an independent state is facing significant challenges in addressing international and domestic events. Kosovo made global headlines when the International Court of Justice declared that Kosovo's unilateral declaration of independence did not violate international law. The country's image in the international arena was seriously tarnished when a member of the Parliamentary Assembly of the Council of Europe, Dick Marty, came out with a report on alleged criminal activities of the Kosovo Liberation Army during and after the war. Kosovo failed to become member of UNICEF but succeeded to become member of UEFA and FIFA. The dialogue between Kosovo and Serbia may improve regional stability and cooperation, but as EU does not have a unified position on Kosovo independence, it may face similar problems when it concerns the outcomes of the dialogue. With BREXIT on one side the Western Balkans enlargement process might slow down. Consequently, the role of pro-European governments (most of them highly corrupted) could fade and this is another opportunity for the euro-skeptic and nationalist parties to come back on stage. In the meantime, the Kosovo Government will continue to struggle for a stable coalition, and their main challenge will be to rally the political potential in order to fight organized crime and corruption. Attempts for the establishment of the Association of the Serbian Municipalities may bring back the oppositions tear gas in Kosovo parliament as it happened for several months in a row in 2015 and 2016. Consequently, the coalition will face with serious difficulties in order to manage and implement fully their executive mandate, specifically in the northern municipalities, in order to build a state with a functional rule of law. 
Within this context, NGO sector as part of civil society can play a positive role and contribution in determining the parameters and the quality of governance while Kosovo's society goes through the complex state building and EU integration processes.

\section{References:}

Council of the European Union, (2006). Council decision of 30 January 2006 on the Principles, Priorities and Conditions Contained in the European Partnership, Official Journal of the European Union.

KHDR (2008). Kosovo Human Development Report, "Civil Society and Development", Prishtina, p 36-39, $45-47,71,90-92,119-123,135-138$,

KIPRED (2005). "A changing civil society-Kosovo's NGO Sector after the War", Prishtina, p 5-7, 10-11, 13$14,16-19,23-24$

LAW NO.03/L-134, 2005 on freedom of association in non-governmental organizations, Ministry of Public Service, MPS, Prishtina, at: http://www.gazetazyrtare.com/egov/index.php?option=com content\&task=view\&lang=en\&id=333 (Last retrieved: June 3rd, 2017)

Progress Report for Kosovo (2008): European Commission, Brussels, at: http://ec.europa.eu/enlargement/pdf/press corner/keydocuments/reports nov 2008/kosovo progress report en.pdf (Last retrieved: June 5th, 2017)

Progress Report for Kosovo (2009). European Commission, Brussels, at: http://ec.europa.eu/enlargement/pdf/key documents/2009/ks rapport 2009 en.pdf (Last retrieved: May 5th, 2017)

Progress Report for Kosovo (2015). European Commission, Brussels, at: http://ec.europa.eu/enlargement/pdf/key documents/2015/20151110 report kosovo.pdf $\quad$ (Last retrieved: May 7th, 2017)

Raik, K. (2006). Promoting democracy in the eastern neighbourhood - the limits and potential of the ENP. The International Spectator, 41(3), 31-45

Spurga, S. (2005). Evaluation of the Impact of the European Integration on the Civil Society of Baltic States. Mykolas Romeris University, Vilnius.

Sterland, B. (2006). Civil Society Capacity Building in Post-Conflict Societies: The Experience of Bosnia and Herzegovina and Kosovo. International NGO Training and Research Centre, Oxford. 
TACSO (2010). Technical Assistance to Civil Society Organizations in the IPA Countries: "Needs Assessment Report", Prishtina, p-13.

USAID, Final Evaluation Report (2008). Kosovo Civil Society Program. 